Abstract

\title{
Evaluation of the Effectiveness of Different Immunostimulatory Medicine at the Experimental Trichinosis and Leishmaniosis on White Mice
}

\author{
Zhdanova, O.B.1,2*; Rudneva, O.V.1; Akulinina, J.K. ${ }^{3}$; Napisanova, L.A. ${ }^{1}$ \\ 1 - All-Russian Scientific Research Institute of Fundamental and Applied Parasitology of Animals and plants \\ (Federal State Budget Scientific Institution) - All-Russian Scientific Research Institute of Experimental \\ Veterinary Medicine K.I.Skryabin and Y.R. Kovalenko the Russian Academy of Sciences. \\ 2 - Kirov State Medical University \\ 3 - Moscow State Medical University named after Sechenov \\ *olgazhdanova70@gmail.com - https://orcid.org/0000-0003-4912-8518
}

Background Immunostimulatory drugs in recent years are widely used in Parasitology. Also, homeopathic drugs such as Cina have anti-helmintic and immunostimulation properties. We studied the possibility of using immunostimulating and high dilutions drugs during parasitological disease treatment. Two experimental parasitological disease models (trichinelosis and cutaneous leishmaniosis) were used. Trichinellosis caused by gastrointestinal nematode Trichinella spiralis occurs in humans, domestic and wild animals. Leishmaniasis is a disease caused by parasites of Leishmania genus. It is spread by certain sandflies types bite. The disease can present in three main ways. We used 2 leishmania in vitro models and experimental mice cutaneous model. The cutaneous form presents skin ulcers, while the mucocutaneous form presents skin, mouth, and nose ulcers. For estimation of immunostimulatory efficacy, size of leishmanioma, presence of leishmania in the ulcer, and treatment time were analyzed. Aims This study aimed at to assess the protective efficiency of homeopathic drug such as Cina $\mathrm{C} 6 \mathrm{cH}$ and interferon 2 and inductors of interferons of types 1 and 2 interferon, against experimental trichinosis and leichmaniosis. Methodology An assay was carried out on 50 white outbred mice. These were divided into three groups of ten mice each. Group 1 was injected with interferon inductors $(2.16 \mathrm{mg} / \mathrm{mouse}$ in $0.2 \mathrm{ml}$ sterile saline, intramuscularly); group 2 - desoldering dissolved in water $\mathrm{Cina} \mathrm{C} 6 \mathrm{cH}$ one time a day per os. The group 3 received interferone$\mathrm{a} 2 \mathrm{~b}$; and the group 4 was injected $0.2 \mathrm{ml}$ of sterile $0.9 \% \mathrm{NaCl}$. The group 5 was only for leishmaniasis. Results and discussion After a 48 hours regimen, the groups 1-3 were inoculated with a dose of 80 \pm 5 units of $T$. spiralis larva per mouse. After 90 days of trichinellosis incubation, and during one year of leishmaniasis process the mice were euthanized and dissected for evaluation. Maximum protection was obtained in mice immunized with interferon-a2b and its stimulatory, as T. spiralis detected larvae in animals was $733.5 \pm 25.1$ larva/animal. Cina $\mathrm{C} 6 \mathrm{cH}$ immunized group presented $2840.5 \pm 183.3$ larva/animal. This was less than control group (4485 \pm 430.6 larva/mouse). Also mice with leishmaniasis had fewer ulcers during treatment with immune stimulating. Ulcers sizes were $0.46 \pm 0.05$ (group 3); $2.2 \pm 0.5$ (group 2), and 3.2+0.8 (group 5). Leishmanial amount in the ulcer was $3.1 \pm 0.7$ (group 3), $3.6 \pm 0.4$ (group 2), and $3.7 \pm 0.3$ (goup 5). The time of the treatment in the 3 -d group was $19.2 \pm 0.9$ and more than 40 days in all group $(2,4,5)$. Conclusion So, based on this, we consider it advantageous to continue the study of immunostimulatory drugs in the complex treatment of trichinelosis and leishmaniosis.

Keywords: immunostimulatory, trichinelosis, leishmaniosis

(C) International Journal of High Dilution Research.

Not for commercial purposes.

OPEN ACCESS 